\title{
Zeolitization in the Neogene formations of Japan
}

\begin{abstract}
The Japanese islands have been subjected to violent volcanism and tectonic movements since early Miocene time. Under these conditions, zeolitization was common in the Neogene formations, especially in the volcanic rocks and volcaniclastic sediments.

Diagenetic zeolitization was pervasive throughout the Neogene basin. Zeolitization by contact metamorphism and by submarine hydrothermal activity appeared as episodes during diagenesis. Since the latest Miocene, when most of the basin was uplifted on land, zeolites also have formed in calderas along the volcanic front and in hydrothermal areas where volcanic activity and tectonic movements were concentrated. In detail, the type of zeolitic zoning is distinctive in each terrain that had a particular geothermal gradient. In general, zeolitization of the Neogene formations in Japan is of a higher temperature type compared to zeolitization elsewhere within the continents.
\end{abstract}

\section{Introduction}

The Japanese islands were situated in a typical active margin of the Asian continent throughout Neogene time. After the opening of the Sea of Japan in the early Miocene, the separated Japanese islands were subjected to violent volcanism and tectonic movements that were caused by the subduction of the Pacific plate. This geologic history is reflected in the sediments that were deposited in a backarc basin ("Green Tuff" region) of middle Miocene to Pliocene age. These sediments include voluminous volcaniclastic materials that were variously altered and that well document the postdepositional history of the subsurface environments of this island arc. Zeolitization especially is a useful tool for analyzing the pressure-temperature $\mathrm{P}-\mathrm{T}$ ) conditions and the chemistry of the subsurface solutions.

\section{Genetic type of zeolitization}

Seventeen species of zeolites (table 1) and many other related authigenic minerals have been identified in the Neogene formations of Japan. They can be classified into five genetic types of zeolitization: (1) diagenetic, (2) contact metamorphic, (3) submarine hydrothermal, (4) caldera-type, and (5) hydrothermal on land. The time range of these five genetic types and the related geologic settings are summarized in figure 1.
Diagenetic zeolitization occurred regionally throughout the Neogene formations that had a thickness of several kilometers. Five diagenetic zones have been recognized according to the assemblage of authigenic minerals, and they are distributed from the top to the bottom of the sequence as follows: fresh glass $\rightarrow$ clinoptilolitemordenite $\rightarrow$ analcime-heulandite $\rightarrow$ laumontite $\rightarrow$ albite (Utada, 1965, 1970). Through increased depth of burial, mineralogical changes may have progressed successively by reactions of volcanic glass and interstitial solutions of seawater origin first to zeolites and then to albite under elevated $\mathrm{P}-\mathrm{T}$ conditions. These changes were accompanied not only by the modification of the texture of the volcaniclastic sediments but also by the chemical differentiation and migration of certain elements on both small and large scales (Utada, 1971). This diagenetic zeolitization typically is found in volcaniclastic sediments of felsic to intermediate composition. On the other hand, several species of calcic zeolites and abundant clay minerals of the smectitechlorite series also were formed in the volcaniclastic sediments of mafic composition.

Numerous igneous masses intruded the Japanese Neogene formations during diagenesis, and they thermally affected the surrounding sediments. A typical example of contact metamorphism has been reported by Seki and others (1969) from the southern part of the Tanzawa Mountains of central Japan. There, the following alteration zones are distributed from the contact to the margin: amphibolite $\rightarrow$ actinolite green schist $\rightarrow$ pumpellyite-prehnite-chlorite $\rightarrow$ laumontitemixed layer chlorite $\rightarrow$ stilbite (clinoptilolite)-vermiculite. However, most of intrusive masses of the Neogene belong to a "volcanoplutonic complex" and are small in size. Their thermal effects were restricted generally to several meters to several hundred meters from the contact, and high-grade zones rarely formed (Utada, 1973).

Table 1.-Abundance of zeolites in the Japanese Neogene formations categorized by genetic type of zeolitization

[(Al), alkalic zeolite; (Ca), calcic zeolite; +++ , abundant; ++ , common; + , rarel

\begin{tabular}{|c|c|c|c|c|c|}
\hline Species & Diagenetic & $\begin{array}{c}\text { Contact } \\
\text { metamorphic }\end{array}$ & $\begin{array}{c}\text { Submarine } \\
\text { hydrothermal }\end{array}$ & $\begin{array}{l}\text { Caldera- } \\
\text { type }\end{array}$ & $\begin{array}{l}\text { Hydro- } \\
\text { thermal } \\
\text { on land }\end{array}$ \\
\hline Analcime (Al) & $+t+$ & + & +++ & + & + \\
\hline Chabazite (Ca) & + & + & & + & +++ \\
\hline Clinoptilolite (AI) & $++t$ & + & & ++ & + \\
\hline Erionite $(\mathrm{Al})$ & + & & & & \\
\hline Epistilbite (Ca) & + & ++ & & & + \\
\hline Ferrierite (Al) & & & + & & \\
\hline Garronite (Ca) & & + & & & \\
\hline Heulandite (Ca) & + & ++ & & + & +++ \\
\hline Laumontite (Ca) & $++t$ & +++ & & +++ & +++ \\
\hline Mordenite (Al) & $+t+$ & + & $+t+$ & +++ & ++ \\
\hline Phillipsite (Al, Ca) & + & & & & \\
\hline Scolecite (Ca) & & & & & + \\
\hline Stellerite (Ca) & & & & & + \\
\hline Stilbite $(\mathrm{Ca})$ & + & ++ & & + & +++ \\
\hline Thomsonite (Al, Ca) & & & & & \\
\hline Wairakite (Ca) & & & & ++ & $++t$ \\
\hline Yugawaralite (Ca) & & + & & & $+t$ \\
\hline
\end{tabular}




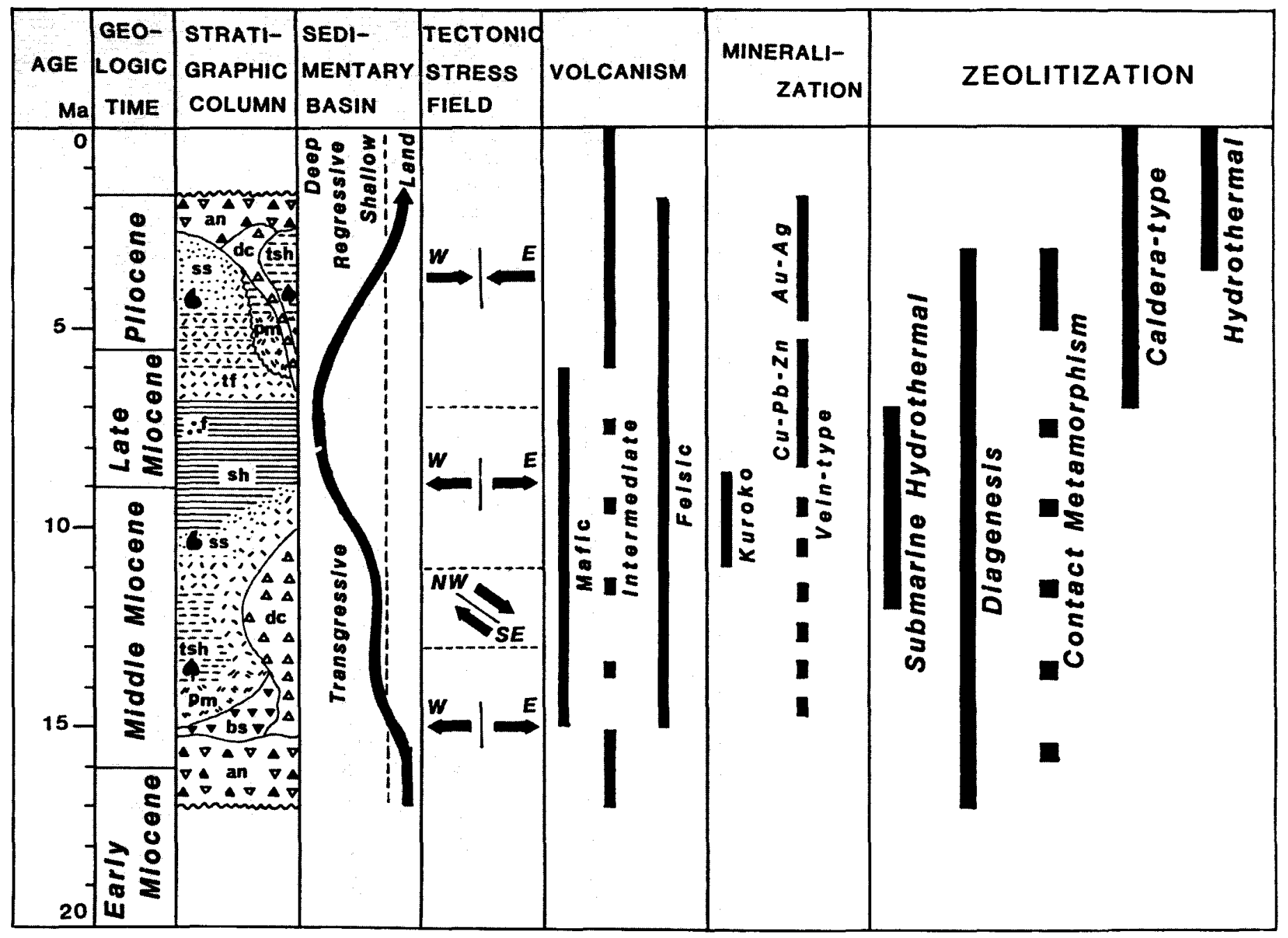

Figure 1.-Summary of zeolitization and the related geologic settings of the Neogene formations in Japan. Abbreviations: an, andesite; bs, basalt; dc, dacite; pm, pumice flow; sh, shale; ss, sandstone; $f$, tuff; tsh, tuffaceous shale; f, foraminifera fossil; $E$, east; NW, northwest; $S E$, southeast; $W$, west.

Zeolites formed by contact metamorphism are mainly the calcic zeolites listed under contact metamorphic zeolitization in table 1.

Submarine hydrothermal zeolitization related to Kuroko-type mineralization (table 1) is noteworthy for its unique occurrence and genesis (Utada, 1988). Literally, "Kuroko" means black ore in Japanese, and the ore consists mostly of sulfides such as chalcopyrite, pyrite, sphalerite, and galena. The alteration zones surrounding a Kuroko deposit are distributed from the ore deposit to the margin as follows: potassium- (K-) feldspar $\rightarrow$ propylite $\rightarrow$ smectite $\rightarrow$ analcime $\rightarrow$ mordenite. The alteration envelope is mushroom shaped. Zeolite zones are distributed in several layers at the margin of the umbrella, which interfingers with the clinoptilolite-mordenite zone of diagenetic origin. This alteration envelope may have formed in two stages. Kuroko ores, K-feldspar, and clay zones formed mainly in the early stage. In contrast, the zeolite zones developed in a later stage when the overlying sediments accumulated rapidly. The rising alkaline hydrothermal solutions of probable seawater origin spread horizontally through porous sediments that were confined by dense cap rocks, and they formed analcime, mordenite, and, rarely, ferrierite during falling temperatures.
Zeolitization that has taken place in caldera-filling sediments is also unique and economically very important (Utada and Ito, 1989). Volcano-tectonic depressions are of latest Miocene to Pliocene age and are as large as $n \times 10^{2} \mathrm{~km}^{2}$ in area and $\mathrm{n} \times 10^{2} \mathrm{~m}$ in thickness $(n=1-9)$. Originally, they were filled mostly by vitric materials that were derived from basal pumice flows. The alteration zones are as follows: wairakite $\rightarrow$ laumontite $\rightarrow$ (analcime) $\rightarrow$ mordenite $\rightarrow$ clinoptil $(-$ lite $\rightarrow$ fresh glass. Zoning is both horizontal and vertical within a nearly flat, panlike basin. The mode of occurrence of zeolites in the high-grade zones is similar to that of the corresponding zones of hydrothermal alteration, whereas the mode of occurrence in the low-grade zones is similar to that of diagenesis. The wairakite zone is rarely recognized. Its appearance, however, is significant as an ind cator of the high-temperature and low-pressure conditions. Characteristically, mordenite is pervasive, and most of the economic mordenite deposits in Japan were formed by this caldera-type zeolitization.

Hydrothermal activity commonly has accompanied volcanism and tectonic movements in Japan since the latest Miocene, especially in the uplifted terrains on land. Various kinds of hydrothermal alter- 


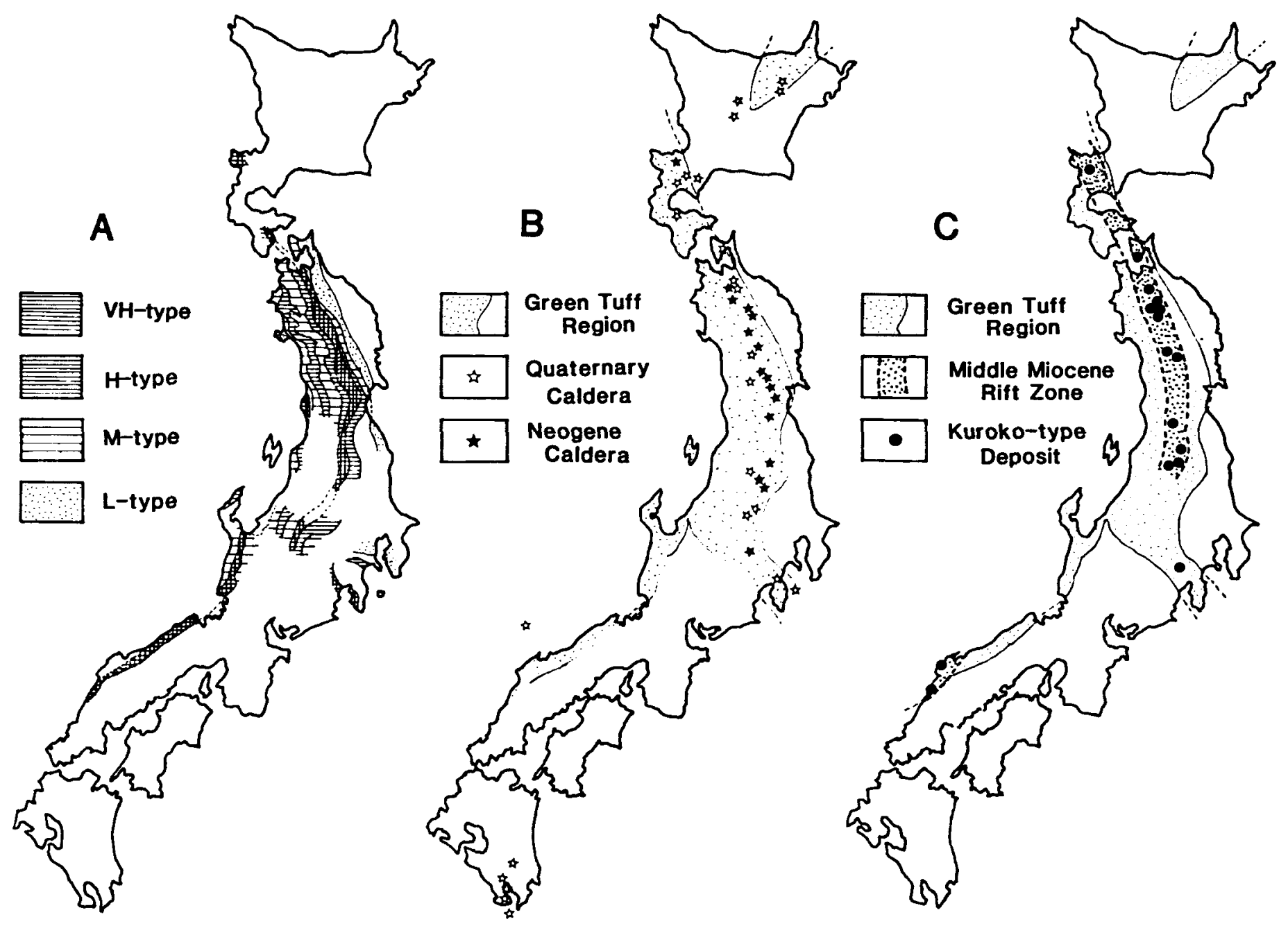

Figure 2. -Distribution in Japan of four types of diagenetic zoning (A), Neogene and Quaternary calderas (B), and Kuroko-type deposits (C). Abbreviations: $V H$, very high; $H$, high; $M$, middle; $L$, low.

ation have occurred mainly along or within faults and fracture zones that were controlled strongly by regional tectonic activity. In the Izu Peninsula, central Japan, 15 species of zeolites are found in these areas of hydrothermal alteration, although zeolitization is minor elsewhere in areas of hydrothermal alteration that is felsic and intermediate in composition (Utada and Shimizu, 1990). Calcic zeolites are predominant as listed in table 1 under the hydrothermal-on-land category. The zeolites commonly occur as large crystals in veins, joints, and cavities.

\section{Time and space}

As already mentioned, zeolitization by diagenesis occurred regionally within the Japanese Neogene basin from early Miocene to Pliocene time. In detail, a transgression had progressed uniformly in the whole basin until the late Miocene. The sedimentary basin, however, was divided into several parts, and the manner of the later regression was different in each part after $7 \mathrm{Ma}$. As a result, the vertical diagenetic zoning is divided into four types according to the succes- sion and the depth of burial of the diagenetic zones (Utada, 1970). The distribution of the four types is subparallel to the Japanese island arc as shown in figure $2 \mathrm{~A}$. VH-, $\mathrm{H}-, \mathrm{M}-$, and L-types of diagenetic zoning represent very high, high, middle, and low geothermal gradients, respectively. In a general way, the VH- and H-types formed during the Neogene in the uplifted terrains after the latest Miocene, whereas the $\mathbf{M}$ - and L-types have formed in the subsided terrains since the same time.

Intrusive masses seem to have invaded the whole area at various stages in the development of the Neogene basin. Their thermal effects on diagenetic zones were generally local, except at several huge masses. Submarine hydrothermal zeolitization related to Kuroko-type mineralization was also episodic during diagenesis. It appeared near the sea floor and was restricted to a narrow rift zone (fig. 2C) along the probable Miocene volcanic front. It was also restricted to a comparatively short time that lasted from the middle Miocene to the early late Miocene. On the other hand, caldera-type zeolitization commonly has appeared on land in uplifted terrain along the volcanic front since the latest Miocene (fig. 2B), and simultaneously, hydrothermal activity began again. Hydrothermal zeolites have formed mainly in the terrains where volcanic activity and tectonic movements were concentrated, especially since $3 \mathrm{Ma}$. 


\section{Physical and chemical conditions of the subsurface environment}

$D_{\text {iagenetic zeolitization has taken place at temperatures ranging }}$ from 40 to $130^{\circ} \mathrm{C}$ under the Niigata oil field (Iijima and Utada, 1971; Sasaki, 1990), under the Akita oil field (Sasaki and others, 1982), and within the Kanto sedimentary basin (Utada, 1968). Each diagenetic zone has a constant temperature range in drill holes of these areas. This fact suggests that diagenetic zeolitization is controlled roughly by the temperature. Under this assumption, the geothermal gradient during the Neogene can be calculated by the depth of burial of the diagenetic zones. The estimated geothermal gradients are in a wide range that varies from more than $100{ }^{\circ} \mathrm{C} / \mathrm{km}$ to less than 10 ${ }^{\circ} \mathrm{C} / \mathrm{km}$. The distribution of the four types shown in figure $2 \mathrm{~A}$ is very similar to that of the geothermal gradients that were estimated by Suzuki (1989) from the vitrinite temperature. Some zeolitization probably developed under very high geothermal gradients that exceeded $100^{\circ} \mathrm{C} / \mathrm{km}$, such as is the case with the hydrothermal zeolitization currently in progress within active geothermal areas. In these areas, the temperature range has been clarified by a large amount of drill-hole data. In general, all zeolitization within the Neogene formations of Japan is of a higher temperature type compared to zeolitization, such as the saline-lake type, found in the southwestern United States, eastern Africa, and other areas within stable continents (Hay, 1966; Sheppard, 1973).

The chemistry of the subsurface solutions seems to be reflected generally in the species of zeolites. Alkalic zeolites form mainly from solutions of seawater origin. On the other hand, calcic zeolites form from heated solutions of both freshwater and seawater origin, probably because of an increase in the $\mathrm{Ca}^{2+} / \mathrm{Na}^{+}$activity ratio by albitization of calcic plagioclase or by the dissolution of mafic minerals.

\section{Acknowledgment}

The writer thanks Dr. R.A. Sheppard of the U.S. Geological Survey, Denver, Colorado, USA, for critically reading the manuscript.

\section{References}

Hay, R.L., 1966, Zeolites and zeolitic reactions in sedimentary rocks: Geological Society of America Special Paper 85, 130 p.

lijima, A., and Utada, M., 1971, Present-day zeolitic diagenesis of the Neogene geosynclinal deposits in the Niigata oil field, Japan, in Flanigen, E.M., and Sand, L.B., cochairmen, International Conference on Molecular Sieve Zeolites, 2nd, Worcester, Massachusetts, USA, 1970, Molecular sieve zeolites, v. 1: American Chemical Society, Advances in Chemistry Series 101, p. 342-349.

Sasaki, A., 1990, Zeolitization in late Cenozoic marine sediments of the Japanese oil producing region: Journal of the Japanese Association of Petroleum Technology, v. 55, p. 1-14.
Sasaki, A., Fujioka, N., and Huzioka, K., 1982, Factors to form the zeolite-zones in sediments during diagenesis (Japan): Journal of the Japanese Association of Petroleum Technology, v. 47, p. 1-11.

Seki, Y., Oki, Y., Matsuda, T., Mikami, K., and Okumura, K., 1969. Metamorphism in the Tanzawa Mountains, central Japan: Journal of the Japanese Association of Mineralogists, Petrologists and Economic Geologists, v. 61, p. $1-21$ and p. $50-75$.

Sheppard, R.A., 1973, Zeolites in sedimentary rocks: U.S. Geological Survey Professional Paper 820, p. 689-695.

Suzuki, S., 1989, The Cenozoic geothermal history of northeast Japan (Japan): Memoirs of the Geological Society of Japan, no. 32, p. $321-337$.

Utada, M., 1965, Zonal distribution of authigenic zeolites in the Tertiary pyroclastic rocks in Mogami District, Yamagata Prefecture: Scientific Papers of the Collage of General Education, University of Tokyo, v. 15 , p. $173-216$.

1968, Migration of chemical components related to zeolitization zoning of Tertiary sediments in the Kanto Basin, Japan: Scientific Papers of the Collage of General Education, University of Tokyo, v. 18 , p. $279-306$.

-1970 , Occurrence and distribution of authigenic zeolites in the Neogene pyroclastic rocks in Japan: Scientific Papers of the Collage of General Education, University of Tokyo, v. 20, p. 191-262.

-1971, Zeolitic zoning of the Neogene pyroclastic rocks in Japan: Scientific Papers of the Collage of General Education, University of Tokyo, v. 21, p. 189-221.

-1973. The type of alteration in the Neogene sediments relating to the intrusion of volcano-plutonic complexes in Japan: Scientific Papers of the Collage of General Education, University of Tokyo, v. 23, p. 167-216.

-1988, Hydrothermal alteration envelope relating to Kuroko-type mineralization, a review: Mining Geology, Special Issue 12, p. 79-92.

Utada, M., and Ito, T., 1989, Sedimentary facies of the Mio-Pliocene volcano-tectonic depressions along the volcanic front in northeast Honshu, Japan, in Taira, A., and Masuda, F., eds., Sedimentary facies in the active plate margin: Tokyo, Terra Scientific Publishing Company, p. 605-618.

Utada, M., and Shimizu, M., 1990, Occurrence, distribution and genesis of zeolites in the Izu Peninsula, central Japan (Japan): Nendo Kagaku, v. 30 , p. $11-18$.

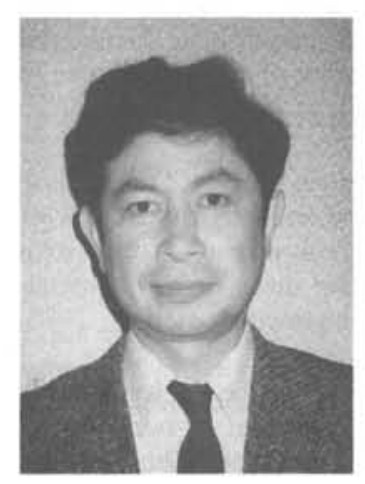

Dr. Minoru Utada has served as Secretary of the Scientific Program Committee of the 29th International Geological Congress. He was an Associate Professor at the University of Tokyo, Faculty of Science, from 1973 to 1985, and he has been at the University Museum since 1985. His speciality is the petrology of rock alteration, including diagenesis, lowgrade metamorphism, hydrothermal alteration, and weathering. $\mathrm{Dr}$. Utada was born in 1937 at Kofu, Yamanashi Prefecture, Japan. He graduated from the University of Tokyo with bachelor's, master's, and doctoral degrees in geology. 